\title{
Life History of Lymnaea columella (Say) and its Experimental Infection with Fasciola hepatica (L.) $)^{1}$
}

\author{
Delfin de León-Dancel
}

\section{INTRODUCTION}

Lymnaea columella first was reported in Puerto Rico by van der Schalie $(1)^{3}$ in 1948. He suggested this snail species may have been introduced, but in a way unknown to him. The author has observed great numbers of this snail in small rivers, streams and ponds in the cattle-raising area from Sabana Seca to Canovanas. This snail is an intermediate host of the common liver fluke Fasciola hepatica (2). This parasite is the cause of great economic loss in Puerto Rico (8) and throughout the world wherever it occurs (4). It thus is necessary to develop a thorough knowledge of the life cycle of this snail species in Puerto Rico and the relationship of the snail and the parasite to the disease fascioliasis here.

\section{MATERIALS AND METHODS}

The snails used in this study originated from a single clutch of eggs laid by a snail collected from a stream in Country Club, Río Piedras, Puerto Rico.

A modification of the culture method of Taylor and Mozley (5) for Lymnaea truncatula was followed. Top soil, freed of stones and large pieces of plant debris, was placed in a large pail. Tap water was added to fill the pail and the mixture stirred vigorously with a large spoon until all plant material floated. The water then was drained off. Enough of the resultant mud was transferred to clear plastic boxes, $27 \times 21 \times 11 \mathrm{~cm}$., to form an evenly sloping 2-inch layer over the bottom. The boxes were kept tilted to maintain the mud slope. Stream material containing green algae, Oscillatoria sp., and other diatoms obtained from the same stream where the snail was collected, was placed on the center of the slope. Plastic box mouse cages, distributed by Disposable Laboratory Cages, Inc., Melrose Park,

1 Thanks are expressed to the following staff members of the University of Puerto Rico: Dr. J. F. Maldonado, School of Tropical Medicine, Dr. J. Chiriboga, Nuclear Center; and Drs. L. Rivera-Brenes, J. D. Rivera-Anaya, J. Bird-Piñero, L. J. Liu and Messrs. R. Woodbury, C. M. Berrocal and J. L. Villalobos, of the Agricultural Experiment Station, for their invaluable advice and assistance in various aspects of the research.

2 Associate Parasitologist, Agricultural Experiment Station, Mayagủez Campus, University of Puerto Rico, Río Piedras, P.R.

Italic numbers in parentheses refer to Literature Cited, p. 305. 
Illinois, were used in this study. These cages have many advantages over earthenware pans or large finger bowls because they are readily available, cheap, non-breakable, and disposable.

When the slopes were firm, the plastic culture boxes were placed in a flat position. About 500 cc. aerated tap water was added and little holes were drilled just above the water level on the side of the plastic boxes to avoid accumulation of rain water. The culture boxes were covered with fine wire screens (figs. 1 and 2) and kept in an $8 \times 12 \times 9$ foot snailhouse covered with green "Saran" plastic ( 46 percent shade) on roof and sides. The room temperature varied from 20 to $30^{\circ} \mathrm{C}$. and the relative humidity from 70 to 98 percent. In about 2 weeks the culture boxes had sufficient algae for use. Leaves of Hibiscus sp. cut into small pieces and boiled for 5 to $\mathbf{1 0}$ minutes were fed three times a week as supplement to the snails.

To observe the various phases of the life cycle of $L$. columella, individual egg masses were scraped carefully from the sides of the culture boxes, placed in Petri dishes with moistened filter paper, and allowed to develop and hatch at a room temperature of $26^{\circ}$ to $28^{\circ} \mathrm{C}$. Newly-hatched snails were raised individually in culture boxes; also in groups of $10,20,30,50$, and 100. The incubation period, initiation of egg-laying and frequency of oviposition were recorded.

Resistance of the snail to dessication was determined by placing twenty 4-week-old snails in each of 10 fresh culture boxes. Numerous egg clutches and young snails were observed in the culture boxes after a month. The water was then drained off and the culture boxes, protected from rain with strong aluminum foil, were kept in the snailhouse. In 20 days the mud slopes were cracked and dried. The aluminum foil covers then were removed and 500 cc. of rain water and several pieces of boiled hibiscus leaves were added. All observations were recorded.

A modification of Plantelouris' method (6) of growing $F$. hepatica was followed for infection of the snails. Gall-bladders from cattle with fascioliasis were collected from a slaughterhouse in Río Piedras, Puerto Rico. They were brought to the laboratory and slit open. The egg-containing bile was collected in a gallon beaker. The beaker was filled with tap water and allowed to stand for 15 minutes during which time the fluke-eggs and bile debris settles to the bottom. The supernatant then was carefully decanted to the bottom half-inch. This operation was repeated until the supernatant fluid appeared clear.

The eggs, together with some liver debris, were resuspended in distilled water and filtered through a 100-gauge $(149 \mathrm{M})$ sieve. The "clean" eggs were spread in a $21-\mathrm{cm}$. finger bowl and kept at $26^{\circ}$ to $28^{\circ} \mathrm{C}$. room temperature. The distilled water was changed daily and the eggs shaken to prevent clumping. 
Snails 8 to $10 \mathrm{~mm}$. in shell length (4- to 6-weeks old) were used for trial infection. For individual infection, 300 snails were washed with a fine jet of distilled water and placed singly in glass vials $(6 \times 2 \mathrm{~cm}$.) containing

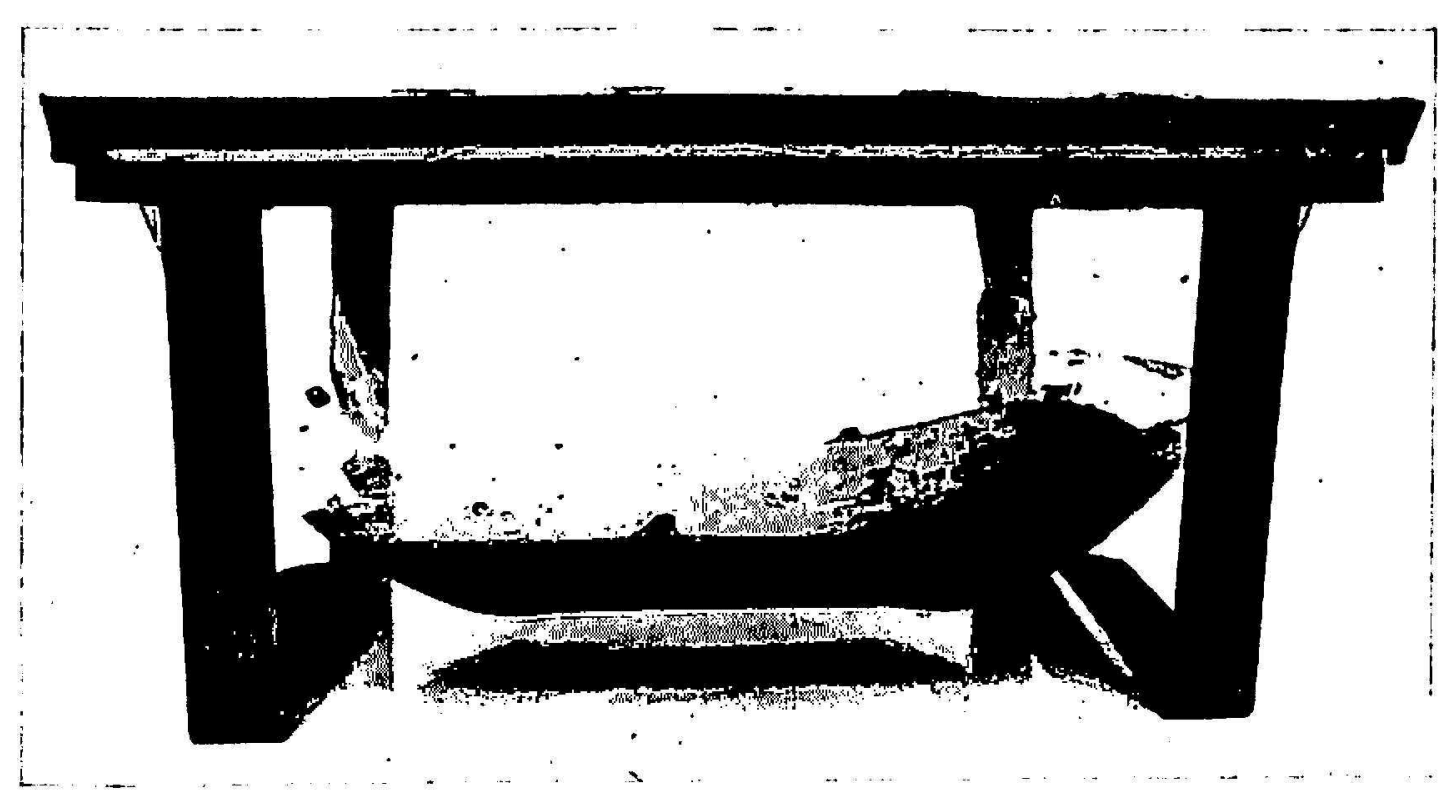

Fig. 1. -Culture box of Lymnaea columella.

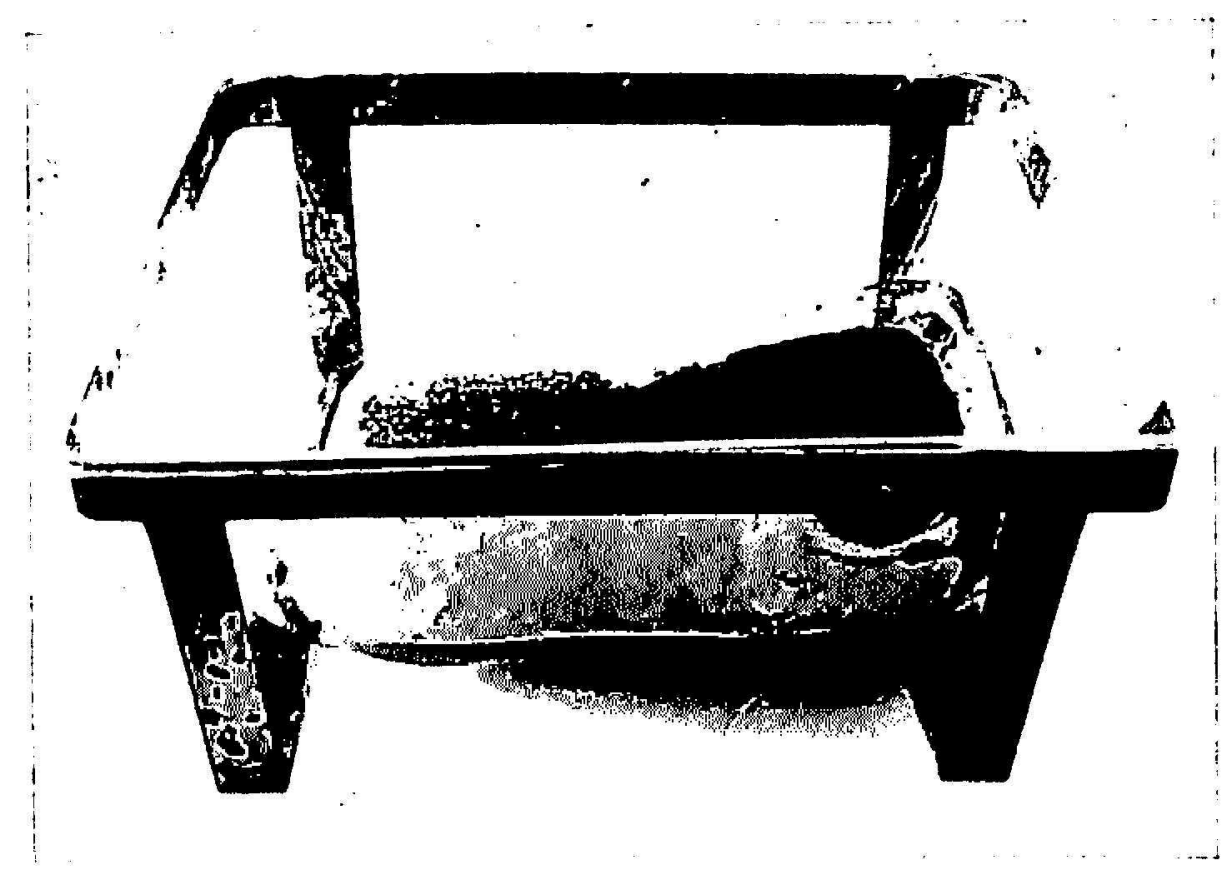

Frg. 2. - Culture box of Lymnaea columella with wire-screen cover removed, showing some snails, mud slope and pool of water at bottom.

the miracidia in 2 cc. distilled water for 3 hours at $28^{\circ} \mathrm{C}$. room temperature. Each of 100 snails were infected with two to four miracidia; another 100 each with four to six miracidia; and the third hundred each with eight to 10 miracidia. For mass infection, 200 miracidia were introduced in each of five 
culture boxes, each containing 20 snails; also, 500 hatching eggs were introduced in each of three culture boxes, each containing 30 snails.

Laboratory-reared mice and rats were fed one and five metacercariae, respectively, to determine if the metacercariae shed by snails were infective.

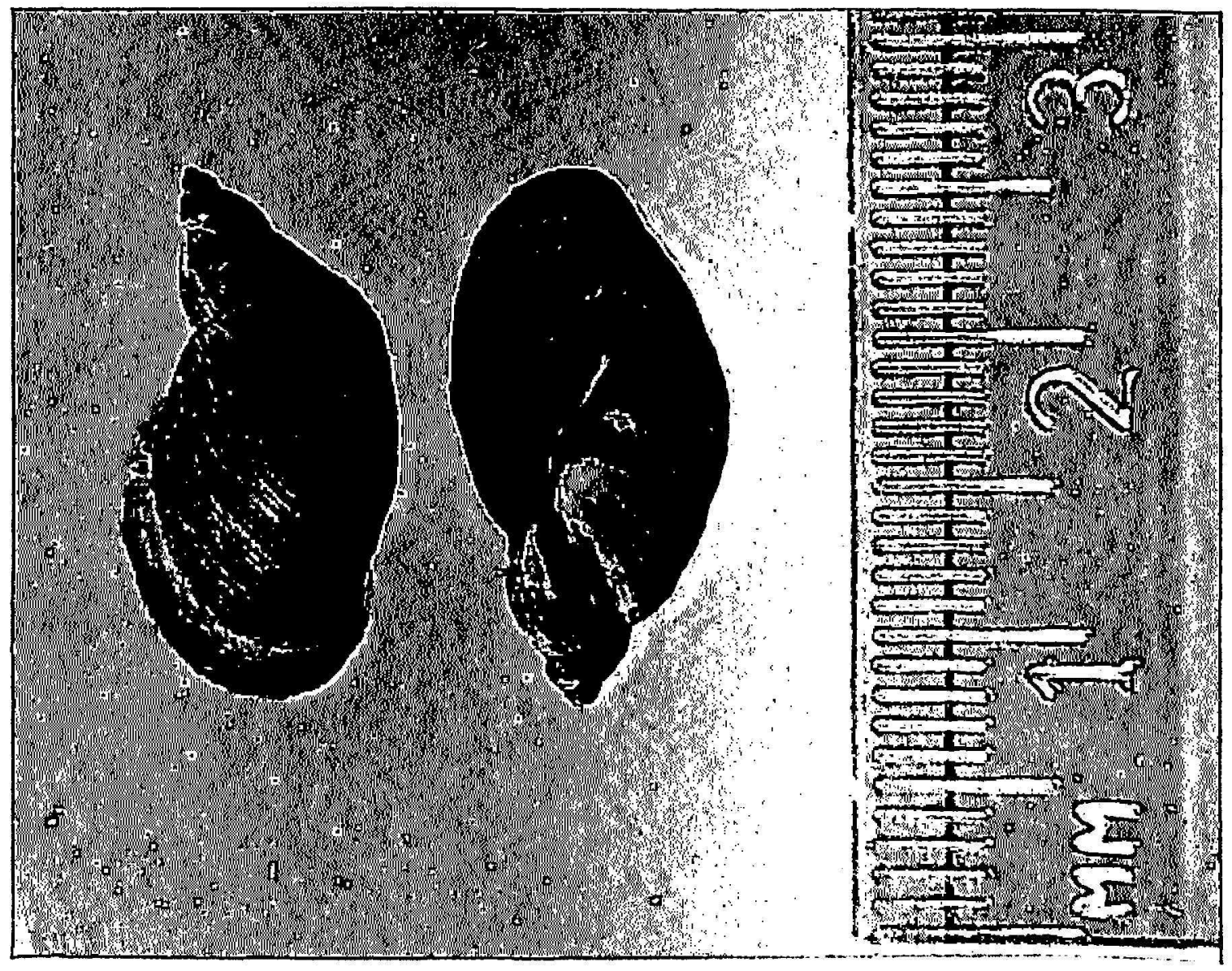

Frg. 3.-Adult Lymnaea columella.

\section{RESULTS}

L. columella (fig. 3) deposits its egg masses usually on the sides of the culture box a few millimeters above water level, at the mud-water junction, and sometimes on the moist mud. The egg masses measure about 6 to 9 $\mathrm{mm}$. long and 3 to $4 \mathrm{~mm}$. wide.

Single eggs are 0.6 to $0.8 \mathrm{~mm}$. long and 0.5 to $0.6 \mathrm{~mm}$. wide. Each egg contains a developing embryo, but twinning is observed occasionally. The number of eggs is variable within each egg mass. A count of 100 egg masses from a colony of 20 snails revealed numbers varying from 12 to 29 ; average 19. Ten snails raised individually and observed over a period of 86 days produced a total of 510 egg masses; eggs per clutch varied from 18 to 61 . Each snail laid an average of 20 eggs per day. The snails as they 
grew older produced progressively larger egg masses and more eggs per mass.

The incubation period of the eggs held at a room temperature of $26^{\circ}$ to $28^{\circ} \mathrm{C}$. in Petri dishes with moistened filter paper on the bottom, was 10 to 13 days. Hatchability was 98 to 100 percent.

L. columella raised in groups of 10 and 20 per culture box reached a shell length of 5 to $6 \mathrm{~mm}$. in 21 to 23 days when egg-laying started. The culture box described provided adequate space for 20 snails to develop and grow well. Mortality rate was low and no transfer or "thinning out" of the snails from one culture box to another was necessary if a sufficient amount of boiled hibiscus leaves was provided as supplementary food. On the contrary, groups of $30,40,50$, or 100 snails denuded the mud slope of algae in a week, grew slowly and the mortality rate was 20 to 30 percent. The life span, based on 20 snail colonies, varied from 112 to 134 days. Some snails grew to be 13 to $16 \mathrm{~mm}$. long, a size rarely observed under field conditions.

Copulation was not necessary for natural reproduction. Kendal (7) observed that $L$. truncatula, isolated immediately after hatching, proved fully fertile and laid large numbers of eggs over a period of months. Corroboratively, our $L$. columella raised singly, oviposited earlier and their egg masses were larger than those of snails raised in colonies of 20 .

Adult snails are very sensitive to desiccation. Only one of 200 snails subjected to a 20-day drying period survived by the fourth day after the culture was remoistened and it lived for only 3 more days. In four other culture boxes three to six young snails ( 1 to $3 \mathrm{~mm}$.) were noted alive after the desiccation period and after 2 months the culture boxes were again full of snail activity. In all 10 culture boxes, one to three intact egg clutches with early embryonic development were observed, but the eggs did not develop. Microscopic examination revealed that all embryos died.

$F$. hepatica eggs hatched within 10 to 13 days at $26^{\circ}$ to $28^{\circ}$ C. room temperature. The miracidia swam very actively and exhibited positive phototropism. Most of them lived for $3 \frac{1}{2}$ hours and the few survivors beyond this span showed only slight activity. According to Pantelouris (loc. cit.), some investigators have reported that the miracidia survived 6 to 8 hours in water at $30^{\circ} \mathrm{C}$. He believes this difference to be due to variation in the liver-fluke strains, or to oxygenation, $\mathrm{pH}$, or salinity of the water.

The results of snail infection with varied number of miracidia are shown in table 1. Snails exposed to two to four and four to six miracidia survived, while those infested with 6 to 10 miracidia died before the cercariae were shed. Snails exposed to two to four miracidia grew better and had a 20percent mortality, compared to those exposed to four to six miracidia, which had 41-percent mortality. Mass infection was effected with 10 to 16 mira- 
cidia per snail in the culture box. An average of eight rediae were obtained from snails a month post-infection. All snails infected en masse with 10 to 16 miracidia died before cercariae emerged.

Snails shed cercariae in 57 to 60 days after exposure to the miracidia. The cercariae encysted within 15 to 20 minutes. Snails infected with 2 to four miracidia produced an average of 312 metacercariae; those infected with four to six miracidia produced an average of 298 metacercariae. All 50 snails observed after shedding cercariae died within 2 to 6 days thereafter.

Mice fed only one metacercaria survived. The first $F$. hepatica eggs were observed in the feces 31 days after infection. Post-mortem examination proved 60 percent of the mice acquired fascioliasis. Rats survived infection with as many as five metacercariae. The first fluke egg in the feces was noted 51 days post-infection. On autopsy, 85 percent of the rats were

TABLE 1.-Exposure of Lymnaea columella to miracidia of Fasciola hepatica

\begin{tabular}{|c|c|c|c|c|c|c|c|c|c|}
\hline \multirow{2}{*}{$\begin{array}{l}\text { Snails } \\
\text { exposed }\end{array}$} & \multirow{2}{*}{$\begin{array}{l}\text { Length } \\
\text { of shell }\end{array}$} & \multirow{2}{*}{$\begin{array}{l}\text { Method of } \\
\text { infection }\end{array}$} & \multirow{2}{*}{$\begin{array}{c}\text { Miracidia } \\
\text { per snail }\end{array}$} & \multirow{2}{*}{ Mortality } & \multicolumn{3}{|c|}{ Surviving snails } & \multirow{2}{*}{$\begin{array}{c}\text { Average } \\
\text { number } \\
\text { of } \\
\text { rediae }\end{array}$} & \multirow{2}{*}{$\begin{array}{l}\text { Average } \\
\text { number } \\
\text { of meta- } \\
\text { cercariae }\end{array}$} \\
\hline & & & & & Total & Positive & Positive & & \\
\hline Number & $\mathrm{Mm}$. & & Number & Percent & Number & Number & Percent & & \\
\hline 100 & $8-10$ & Individual & $2-4$ & 20 & 80 & 70 & 87 & 一 & 312 \\
\hline 100 & $8-10$ & Individual & $4-6$ & 41 & 59 & 56 & 94 & - & 298 \\
\hline 100 & $8-10$ & Individual & $6-10$ & 100 & 0 & 一 & - & - & - \\
\hline $100^{1}$ & $8-10$ & Mass & 10 & 10 & 90 & 65 & 72 & 8 & - \\
\hline $100^{1}$ & $8-10$ & Mass & 16 & 24 & 66 & 63 & 93 & 8 & - \\
\hline
\end{tabular}

1 Dissected for rediae after 1 month of exposure.

positive with one to four flukes. The flukes fixed with corrosive sublimateacetic acid and kept in 70 percent alcohol measured from 11 to $13 \mathrm{~mm}$. in length and 4 to $5 \mathrm{~mm}$. in width.

\section{DISCUSSION}

Snails of Lymnaea columella (Say) are found under field conditions in slow-flowing rivers, streams, and ponds containing some plant growth and sometimes virtually choked with vegetation (figs. 4 and 5) where they deposit their eggs on floating pieces of debris and at the waterline on the river bank. They are most numerous from November to April during the dry period of the year.

There is little doubt, based on this experiment, that $L$. columella plays an important role in the perpetuation of cattle fascioliasis in the northern part of Puerto Rico. Temperature and humidity in this area is most favorable for its growth and development. The fact that young snails withstand a 20-day dessication period under laboratory conditions is an indi- 


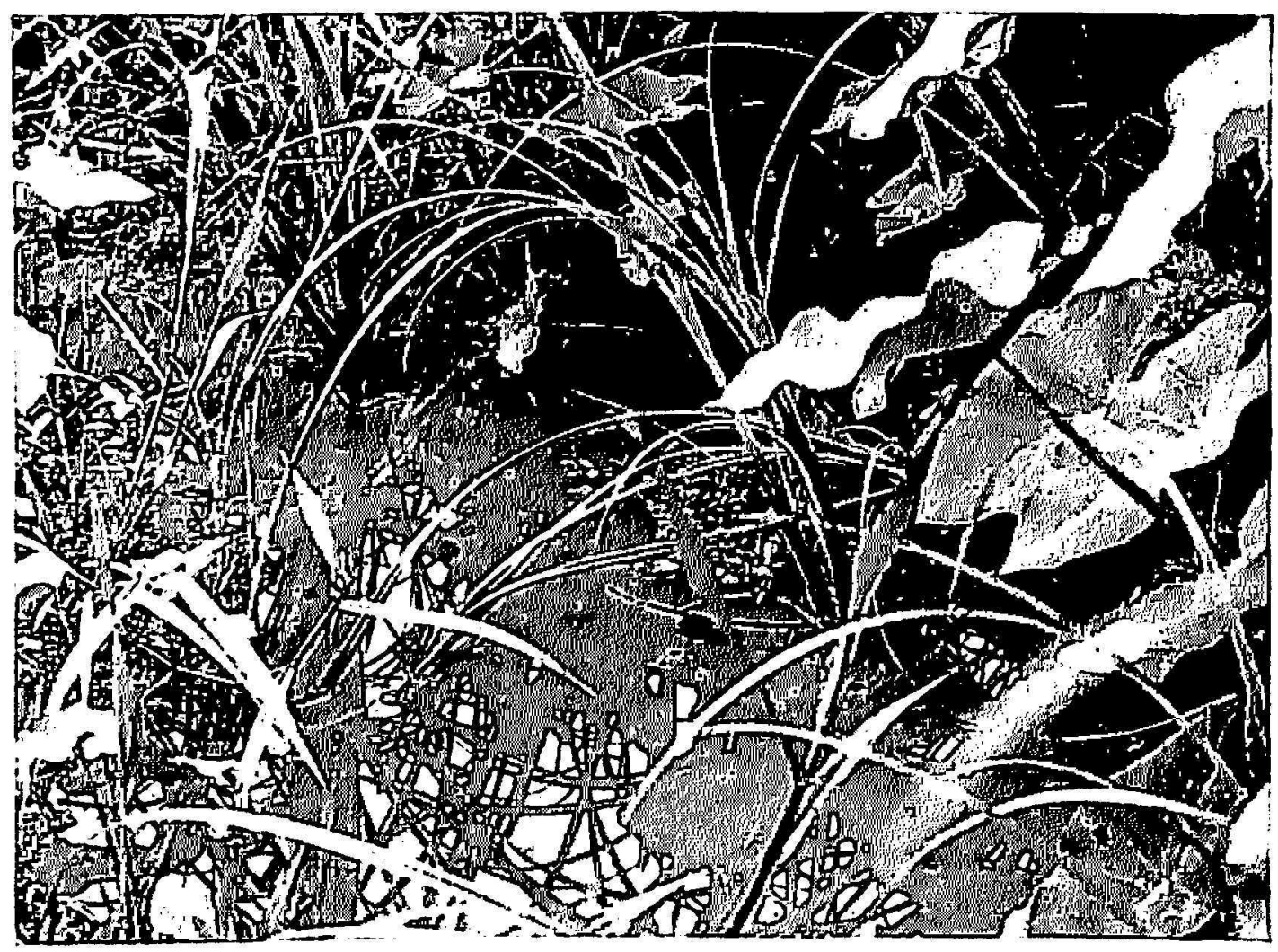

Frg. 4.-Habitat of Lymnaea cloumella in Canovanas, Puerto Rico. Ditch dug to drain pasture.

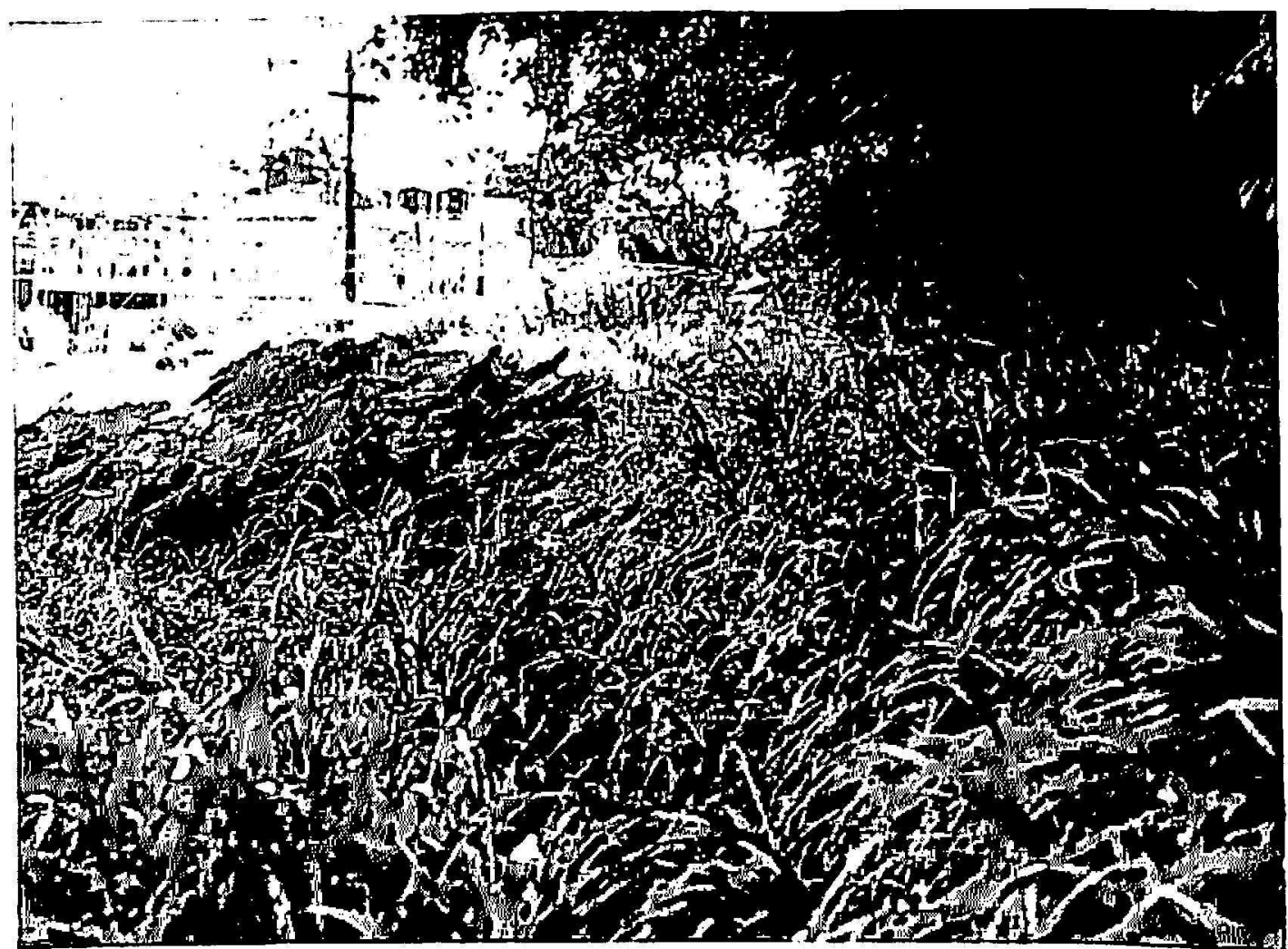

Fra. 5.-A permanent habitat of Iymnaea columella behind the ARS Building at the Agricultural Experiment Station, Univ. of P.1R., in ditch practically choked with vegetation. 
cation that this snail should be watched most carefully because no pronounced drought periods occur in northern Puerto Rico. Proper measures must be instituted to prevent spread of $L$. columella. Regular examination and treatment of cattle infested with fascioliasis should be a minimal part of continuous regulatory procedures.

\section{SUMMARY}

The life history of Lymnaea columella was studied under laboratory conditions at Río Piedras, Puerto Rico.

The snail matured in 21 to 23 days after hatching, when shell length was 5 to $6 \mathrm{~mm}$. A culture box $27 \times 21 \times 11 \mathrm{~cm}$. provided adequate space for a colony of 20 adult specimens. A mature snail raised individually produced an average of 20 eggs daily. The incubation period of the eggs at $26^{\circ}$ to $28^{\circ} \mathrm{C}$. varied from 10 to 13 days with 98 to 100 percent hatchability. Both eggs and adult snails were highly sensitive to desiccation; not so young snails.

To test the behavior of $L$. columella under stress of infection with $F$ asciola hepatica, adult specimens were exposed to a variable number of miracidia. These were obtained by cultivation of eggs from the gall-bladder of infected cattle. The miracidia hatched in 10 to 13 days at $26^{\circ}$ to $28^{\circ} \mathrm{C}$. and did not live more than 31/2 hours. Snails receiving 2 to 4 miracidia tolerated the infection well with low mortality but died within 2 to 6 days after cercariae started emerging. Specimens receiving four to six miracidia were able to survive but the mortality rate was high. Inocula of 10 to 16 miracidia caused early death of the snail.

The cercariae, released from the snail in 57 to 60 days after infection, encysted within 15 to 20 minutes to become metacercariae. Mice tolerated infection with one metacercaria; rats, with five metacercariae. Eggs first were observed in feces at 31 and 51 days post-exposure in mice and rats, respectively.

\section{RESUMEN}

Se estudió el ciclo vital de Lymnaea columella bajo condiciones de laboratorio en Río Piedras, Puerto Rico.

Este caracol alcanza su condición de adulto entre los 21 y los 23 días de nacido, cuando la concha mide entre 5 y $6 \mathrm{~cm}$. de largo. Una caja sementera de $27 \times 21 \times 11 \mathrm{~cm}$. provee espacio suficiente para una colonia de 20 caracoles.

Un caracol adulto, criado aisladamente, produjo un promedio de 20 huevos diarios. Del 98 al 100 por ciento de los huevos incubaron entre los 10 y los 13 días, a una temperatura de $26^{\circ}$ a $28^{\circ} \mathrm{C}$. Tanto los huevos como los caracoles adultos fueron muy sensitivos a la desecación, más no así los caracoles jóvenes. 
Se observó el comportamiento de los adultos de $L$. columella expuestos a la acción infectiva de cantidades variables de miracidios de Fasciola hepatica. Los miracidios se obtuvieron mediante el cultivo de huevos de fasciola recobrados de la vesícula biliar de bovinos afectados por dicho trematodo. El miracidio nace del huevo de los 10 á los 13 días a una temperatura de $26^{\circ}$ a $28^{\circ} \mathrm{C}$., y vive no más de $3 \frac{1}{2}$ horas. Los caracoles invadidos por 2 a 4 miracidios resistieron bien la infección, registrándose una mortalidad baja; sin embargo, murieron entre los 2 y los 6 días de haber comenzado a emerger las cercarias. Una menor proporción de caracoles infectados por 4 a 6 miracidios sobrevivieron, mientras que los infectados por 10 a 16 murieron prematuramente.

Las cercarias emergieron de los caracoles infectados entre los 57 y 60 días y se enquistaron entre los 15 y 20 minutos después para tornarse en metacercarias. Los ratones toleraron las infecciones causadas por una sola metacercaria, mientras que las ratas toleraron infecciones con cinco. Se observaron huevos de fasciola por primera vez en el excremento de los ratones y las ratas a los 31 y 51 días después de la infección, respectivamente.

\section{LITERATURE CITED}

1. Van der Schalie, H., The land and fresh water mollusks of Puerto Rico, Misc. Publ. Mus. Zool., Univ. Mich. No. 70, 100-101, 1948.

2. Van Volkenberg, H. L., An annotated check list of the parasites of animals in Puerto Rico, P. R. Exp. Sta. Circ. 22, 1939.

3. Rivera-Anaya, J. D., and Martínez-de Jesús, J., The extent of liverfluke infection of cattle in Puerto Rico (A slaughterhouse survey), Agr. Exp. Sta. Univ. P. R. Bull. 107, 1952.

4. Sinclair, K. B., Pathogenesis of Fasciola and other liver-flukes, Helminth. Abstr. $\$ 6$ (2): 115-34, 1967.

5. Taylor, E., L. and Mozley, A., A culture method for Lymnaea truncalula, Nature 161: 894, 1948.

6. Pantelouris, E. M., The Common Liver-fluke, Fasciola hepatica L., 1st ed., Pergamon Press, New York, p. 197, 1965.

7. Kendall, S. B., The life history of Lymnaca truncatula under laboratory conditions, J. Helminth. 27: 17-28, 1953. 